\title{
German Foreign Policy Determinants under Merkel Custody (2005-2014)
}

\author{
Bouhania Goui \\ Professor and Dean \\ Faculty of Law and Political Science \\ Ouargla University, Algeria \\ Oussama Bouhmama \\ PhD Student \\ Ouargla University \\ Algeria
}

\begin{abstract}
The Foreign Policy of any state means permanent interests as a fundamental feature of its policy, given that in the political field it is claimed that there are neither permanent friends nor enemies, but permanent interests. In other words, the foreign policy combines a powerful strategy of any given state, viz., its national security and the nature of its political relations with other countries. Therefore, Foreign policy helps in defining the position of the state and directs its personalities. Drawn on the three levels of foreign policy, this article explores how the internal and external factors influence the German foreign policy.
\end{abstract}

Keywords: Anarchism, decision maker, security policy, foreign policy determinants.

\section{Introduction}

This Article is intended to find out the extent of the reflection of internal and external factors on the overall variation in German foreign policy. The analysis of these factors will be in accordance with the known theoretical frameworks for the three levels of foreign policy analysis. First, the International system level: it is wherein the anarchic structure of the system as well as the nature of the distribution of power consist. Second, it is the national and internal level, which is the decision-makers at the official level, and social and other actors such as media and interest groups on the social informal level, given the difference in the nature of the ruling elite and the outlook for the country's role in the international arena. Finally, it is the institutional level, which refers to the international organizations and military alliances which the state operates with, such as the United Nations and NATO.

Obviously, the United Nation's impact as a Determinant of German foreign policy is big for many reasons, the most important of which is, first, Germany does not have veto power, secondly, Germany owns and depends on low military capacity, thirdly German tends always to teamwork, and often work to unite a common European position, especially in the areas of defense policy, finally the NATO has more of a role in German foreign policy then the United Nations.

German foreign policy considered one of the most significant policies in the world. It is a state which allied with NATO security and an effective actor internationally and regionally. To understand the nature of German policy we must know the framework within which the German government runs in, this framework is in turn governed by a group of internal and external factors that actually represent the determinants of foreign policy of the State Therefore you cannot understand the variation in German foreign policy without analysis of these determinants and find out the extent of their impact on the making and directing this policy.

The making of Foreign policy of states, is usually affected by multiple internal and external determinants, which can be discussed at three levels of analysis of foreign policy; the level of the international system, which includes the structure of the system and whether it is anarchist or ordinal, The nature of the distribution of power, whether it is bilateral, unipolar or multipolar. The national level, which includes the decision maker and the nature of the political system at the official level, interest groups and the media and public opinion at the social level; and finally, the level that includes bilateral or collective institutional structures that participate or interact states in the framework such as international organizations and alliances, or collective and bilateral agreements ( $\left.{ }^{\text {Dunne }}, 1999\right)$. 


\section{International System Level}

This level deals with the analysis of the states' position and rank in the international system on the one hand, and the nature of the distribution of power in this system on the other. This level is divided into threedeep sub-levels which are profound in structure, distributional structure, and the institutional structure ( ${ }^{\text {Brown }}$, Lynn-Jones $\&$ Miller, 1995$)$.

\subsection{Anarchism as an organizing principle}

Foreign policy is an organization process management for countries, and its relations with the outer perimeter, and that it is normal to be affected by the developing events taking place in the environment. This policy aims primarily to protect and promote national interests (Jäger \& Rasmus, 2007), and it is usually the goals linked to capacity available of state-owned For this, the nature of power that owned by states pose a determinant prime to implement its foreign policy, for many reasons most important one that the current structure of the international system is anarchic, which is mean the absence of a world government or central states to protect and preserve the interests so the Absence of such power that can protect treaties between states and apply the rules of international law, makes the States take all the responsibility to protect themselves and their interests And therefore it directs its external behavior to ensure its political existence, on the one hand, and enhances its regional or international position, on the other hand, as a result to achieve its national interests. Also countries may not be able to achieve national goals by their own, especially in the absence of a centralized global authority; they need to interact with the outer perimeter. this needs may differs by the differences in conditions and capabilities If powerful countries were able to provide protection for themselves and secure their existence, the least strength states may not be able to achieve it only through cooperation with other countries, and to enter into bilateral or multilateral alliances, or join supranational organizations which help them to make up the shortfall in capacity and then provide protection to its existence and the preservation of its interests ( ${ }^{\text {Waltz }}, 1993$ ).

As much as regard to Germany the anarchist has negative significant impact on the German Foreign Affairs. The absence of a global authority is in fact an important determinant. Sometimes, these policy makers may be forced to adopt attitudes which are contradictory to the principles they believe in, or underlying their international relations. German military and economic capabilities are comparatively modest compared to the capabilities of other world countries such as (United States, Russia). Germany is forced to focus on the work in a collective framework through the European Union and the United Nations in order to achieve their interests and dealing with international issues of interest to them. Germany does not have the status of World domination compensated for the absence of central authority and give it greater ability to move and act in the international arena. Germany is forced to focus on the work in a collective framework through the European Union and the United Nations in order to achieve their interests and deal with international issues that care of. Germany does not have the World domination position repay her the absence of central authority and give it greater ability to act in the international arena.

\subsection{Structure distribution of power}

The structure of the international system constitutes an important determinant and a key restriction on the foreign behavior of states After the end of the Cold War and the collapse of the Soviet Union, bipolarity disappeared and the United States became the only superpower in the world According to the theory of structural realism presented by "Kenneth Waltz," the only superpower must have all kinds and forms of power $\left({ }^{\text {Jäger }}, 2007\right)$.

This is largely true to the United States now. Since the collapse of the Soviet Union in 1991, the United States became the only state in the world, which has all forms of military, economic, technological and geopolitical power. For the first time in modern history, there is a big gap in capabilities between the United States and the second force in the world, Russia. Unilateral system represents a key determinant in German foreign policy, and limits the options available of the German especially when there is a conflict of views or a clear difference in perceptions. This is contrary to what was the case during the Cold War, where bipolarity gave more space to the allies of the United States to move. But now under almost absolute of the US unilateralism control the international system, Germany should have the balance between its alliance with the United States, which sometimes may require making concessions or perhaps follow the US policies towards some of international issues, and its National interests that may require opposing these policies sometimes. 


\subsection{Institutional Level}

This level deals with bilateral or multilateral interactions between states within the frameworks or institutional structures that it shares. This structure has the special attention from the neo-liberals who see it as a positive element in the growing influence of interactions between states and There is no state can live alone isolated from the world because of the growing interdependence between countries, and this is what pushes states to cooperate with each other through bilateral agreements or resorting to international and regional organization., it may help to shape the behavior of states and affect their interactions, and this is obvious in the case of the formal alliance between the United States and Europe in the institution of NATO. Germany focuses on standard aspect in international relations, which respecting the standards and values shared by the UN keeping with accepted practices in the modern era, the United Nations has an impact on the foreign policy of the states through different means, such as penalties and using of military force. German concept of collective work is the German confirmation on the role of the United Nations, and trying to work through which to influence the foreign policy of other countries. It is without doubt less able to achieve this broad influence because they do not have the same influence, which is owned by states such as America or Russia, and that it seeks to make up the shortfall in this area by acquiring a permanent seat in the Security Council ( $\left.{ }^{\text {Hellmann }}, 2004\right)$.

As for Germany, it considered to NATO security and defense organization in the base, used to protect Europe. That is why they are trying to use NATO as a means of activating the role of Europe globally and also used to influence on US policies (Crawford, 2007).

In short, the level of the international structure, as we are dealing with it here is a somewhat uniform approach which brings together the elements of the new realism and structural realism and neoliberals, including the deep, the distributional and the institutional structure. These levels are different branches that help us achieve a clearer view of the position of the units in the international system on the one hand, and on the other hand, it determines the effect of the structure of the international system on the external behavior.

\section{National Level}

The national level is one of the most important levels of analysis in international relations. The state, according to the theories of realism, is the main unit of analysis in the international system, simply because it was and still is the first actor in all types of international interactions ( $\left.{ }^{\text {Mouritzen }}, 1997\right)$. This automatically means that the other actors, non-state and transnational actors, are of less importance, and are sometimes not included in the analysis. At this level, the analysis includes the properties of an internal state, the most important of which include: the nature of the ruling regime, the type of government, institutional capabilities, the degree of internal stability, and the extent of the industrial and economic progress. This level of analysis is also looking at the role of the different institutions and forces in society to know the extent of their impact on the external behavior of the state The focus here is not only the interests of the bureaucracy or political groups, but it may sometimes extends to other factors such as the distribution of power and the relationship between state and society and the power of the state itself ( $\left.{ }^{\text {Gourevitch }}, 1996\right)$.

Here, we highlight the need to develop theories dealing concurrently with interactions between internal and international factors. Therefore, the decision-maker must be reconciling between the internal and national priorities among international external conditions. The use of this approach is important to determine the real impact of the internal structure of the state policy on the external behavior.

As mentioned above, we analyze the most important internal and external determinants that affect the process of the German foreign policy making in the following:

\subsection{Decision maker level}

As it's the case for the factors for the level of the international system, the nature of the impact of main people in the decision-making process differ, For Germany, the counselor for a key role in foreign policymaking; but he does not have right of the monopoly on this process, as is the case in other presidential systems.

Foreign Minister of Germany in the role of an actor highly depends on the nature of the government coalition which may be the Chancellor of the party, as is the case for the current Chancellor Angela Merkel (Christian Party), and Foreign Minister from another party As the case for Steimr (of the Socialist Party). Thus, the nature of the relationship between the Chancellor and foreign minister plays a key role in the direct making of German foreign policy. 
The Chancellor in Germany cannot make decisions at foreign level without the approval of his party on the first side, and his coalition partners on the other side. Therefore, the nature of governance and sharing of responsibilities imposed by the existence of the coalition between the major parties, are considered important determinants of the German foreign policy-making process $\left({ }^{\text {Hacke }}, 2006\right){ }^{1}$

\subsection{Historical context and its impact on decision-makers to see the role in the state}

For Germany, it has been a dominant force in Europe, as a result of the imbalance of power twice: first at the beginning of the twentieth century, and the second in the second quarter of it, it has been two world wars. The result of it was not only the destruction and defeat of Germany, but also its occupation and blame Germany to take full responsibility for the war and all its accompanying combination like "Massacres which Israel says that the Nazi regime had committed against the Jews in Europe." And therefore the defeat of Germany in the war and blaming her for main Responsible of it, made a motivation for the German elites to adopt a wise foreign policy which is not based on the use of force, violence or the desire for global hegemony or even regional control, Because of this new vision was formed in Germany by official and popular levels based on the adoption of a purely peaceful policy, and to focus on the economy and trade. Germany started to take new traditions shape of foreign policy quite different from those that dominated for decades since the founding of the First Reich and until the end of the second war. The first German government has worked on that after the occupation in 1949, led by Adenauer to dedicate this trend, Successive governments, including the Socialist and Christian continued to adopt a very quiet foreign policy based on the principles of the most important multilateral action and respect for international law and not to engage in any armed conflict (Crawford, 2007).

\section{Component:" Interest Groups"}

There are other internal determinants of foreign policy, not only decision-makers or official levels, but also the most important of these actors is public opinion, the media and the political parties and interest groups, actors' and social power's impact on the German process of foreign policy-making, through opposition or approval of what the authority in foreign relations. Public opinion and the media affect the foreign policy orientations of the government and decision-makers. Both actors are interrelated dramatically. The media works to raise public awareness of orientations, and of the dominant foreign policy. It also, at the same time, contributes mainly in guiding and shaping public opinion about this policy, which is important for the decision-maker in order to get public support from the legislative to his foreign policy orientations. The media therefore plays the role of mediator or link between public opinion and foreign policy makers.

In Germany, the biggest foreign policy impact is of the political parties, because of its choice, and because it served its members of parliament and the government. However, the overall impact is not critical because the decisions are shaped and usually taken by the party leadership. As for interest groups, they try to influence foreign policy through the lobbies which often have an impact on official actors in the executive and legislative power, or through indirect control, or through manipulating and influencing public opinion. However, the amount of the impact of these groups and their role as a determinant of foreign policy depends largely on a set of norms including their spread and mobilization, the ability to adapt, human and material resources, and then the prospects for entry into direct political action.

\section{Conclusion}

The subject of foreign policy did not get its rightful place among the scientific and political comparative studies because most of the studies on this subject have been confined to the descriptive analysis of the institutions and political processes within each state. The study of international relations focused on links states relationships to each other and discussed balance of power between different countries and ideological differences and settle their disputes within the scope of the treaties or international organizations, While foreign policy which is the most important aspect of international relations have no place in these studies.

\footnotetext{
1Lecture by Professor Dr. Christian Hacke, "Die Bedeutung von Personen und ihren Beziehungen im deutsch-amerikanischen Verhältnis nach dem Zweiten Weltkrieg" \{The Concept of Persons and their relations in the German-American relationship after the Second World War\} 09.11.2006 im Rahmen des Hauptseminars Deutsche und amerikanische Außenpolitik im Vergleich des Lehrstuhls für internationale Politik und Außenpolitik der Universität zu Köln.) p. 11
} 
The world has witnessed several serious transformations, Evolution technological and military made the Human values and human conscience threatening, after when European were the main actors in the international system the focus shifted to a bipolar system "united State and the Soviet Union earlier", in that time military and the technological competition reached its apogees it was the beginning of the emergence of new ways to win the competition and enhance the control and exploitation and by that it appeared a states which gained great importance as a center for international competition and exploit markets such as Latin America, Middle East, Africa, South Asia and Southeast Asia.

In recent decades, attention to studies that relate to the foreign policy of the States and to the important role it plays in the international arena has been increased, also Studies which discussed the inner side of the state and its influence on the decisions and interaction of foreign policy expanded, Because studies have begun to take the dynamic social character.

German foreign policy clearly has evolved in response to a series of strategic dilemmas in the post-Cold War era, and this paper explained the importance of domestic conditions that shaped foreign policy restructuring over time.

The model of external-internal linkages has proven useful for understanding decision making in both the Conservative-Liberal coalition of the immediate post-Cold War era, as well as more recent actions by the Social Democrat-Green government. The evolution of German foreign policy activism from the Gulf War to Kosovo, the war on terrorism, and beyond, will have a profound impact on the country's position in the new century. Studying German's foreign policy reviews model of evidence and draws conclusions about the theory and practice of foreign policy restructuring in period of Markel government (2005-2014).

\section{References}

Brown, Michael E., Lynn-Jones, Sean M. and Miller, Steven E., (eds.), The Perils of Anarchy: Contemporary Realism and International Security, Cambridge, MA: MIT Press, 1995.

Crawford, Beverly. Power and German Foreign Policy Embedded Hegemony in Europe, Macmillan Publishers Limited, Hampshire, 2007.

Crawford, Beverly. Power and German Foreign Policy Embedded Hegemony in Europe, Macmillan Publishers Limited, Hampshire, 2007.

Dunne, Timothy "Realism," in Baylis and Steve (ed.), The Globalization of World Politics: An Introduction to International Relations, Oxford: Oxford University Press, 1999.

Gourevitch, Peter A., "Squaring the Circle: The Domestic Sources of International Cooperation," International Organization, Vol. 50, No. 2, Spring1996.

Hacke, Christian. "Die Bedeutung von Personen und ihren Beziehungen im deutsch-amerikanischen Verhältnis nach dem Zweiten Weltkrieg" \{The Concept of Persons and their relations in the German-American relationship after the Second World War\} 09.11.2006 im Rahmen des Hauptseminars Deutsche und amerikanische Außenpolitik im Vergleich des Lehrstuhls für internationale Politik und Außenpolitik der Universität zu Köln.)

Hellmann, Gunther. "Ex occidente Lux...Warum der deutsche Anspruch auf einen ständigen Sitz im UNSicherheitsrat schlecht begründet ist und wie Deutschland auf anderem Wege _dauerhaft mehr Verantwortung übernehmen' kann“, in: Politische Vierteljahresschrift, Jg. 45 (2004), Heft 4.

Jäger, Thomas and Rasmus, Beckmann. "Die internationalen Rahmenbedingungen deutscher Außenpolitik", in: Jäger, Thomas/Oppermann, Kai/Höse, Alexander (Hrsg.): Deutsche Außenpolitik, Wiesbaden i.E., 2007.

Jäger, Thomas. Deutsche und amerikanische Außenpolitik im Vergleich. Köln: Jeannine Hausmann, 2007.

Mouritzen, Hans and Waltz, Kenneth. "A Critical rationalist between International Politics and Foreign Policy," In Iver B. Neumann and Ole Wæver (eds.), The Future of International Relations. Masters in the Making, London: Routledge, 1997.

Waltz, K. "The Emerging Structure of International Politics," International Security, Vol. 18, No. 2, Fall 1993. 